\title{
The effect of the process condition on synthesis amorphous silica alumina from metakaolin on pore structure and crystallinity of product
}

\author{
Endang Sri Rahayu ${ }^{1}$, Gatot Subiyanto $^{2}$, Shoerya Shoelarta $^{2}$, Marvin Indi Hartono ${ }^{2}$, and Hagai Elisafa ${ }^{2}$ \\ ${ }^{1}$ Department of Chemical Engineering, Bandung State Polytechnic, Jl. Gegerkalong Hilir, ds.Ciwaruga, Bandung 40012, \\ Indonesia
}

\begin{abstract}
The objective of the research to study the effect of amorphous silica alumina (ASA) synthesis condition on pore structure and crystallinity. Synthesis of ASA was done by co-precipitation method, that preceded by neutralization to form a sol phase, followed by introducing a silica solution, and then aging to form an amorphous phase. Alumina solution is resulted by leaching of metakaolin from kaolin Belitung, Indonesia. The use of alumina source from this kaolin is a novelty method. Process conditions synthesis of ASA were varied on $\mathrm{Si} / \mathrm{Al}$ ratio, time of neutralization and time of aging. While, a $\mathrm{pH}$ and temperature of neutralization are as independent process variable, of 7-8 and $50-55{ }^{\circ} \mathrm{C}$, respectively. Characterization of ASA was performed using XRD, surface area and pore analyzer. The increasing of Si/Al ratio in starting material affects on the surface area of ASA, as well as with aging time. The best product of ASA with a specific surface area of $510 \mathrm{~m}^{2} / \mathrm{g}$, average pore diameter of $85 \AA$, a total pore volume of $1.1 \mathrm{~mL} / \mathrm{g}$, and an amorphous phase of 53\%-mass were observed.
\end{abstract}

\section{Introduction}

Amorphous Silica Alumina (ASA) is an inorganic polymer, composed of components identical to zeolites. The ASA structure is irregular, in its structure there are also tetrahedral units of $\mathrm{SiO} 4$ and $\mathrm{AlO} 4$ which build a three-dimensional framework. ASA has a mesopore-sized diameter, greater than the pore diameter of the zeolite Y of $7.4 \AA$ [1-3]. The nature of ASA is strongly influenced by the methods and operating conditions of the manufacturing process [4].

Amorphous Silica Alumina (ASA) are built by atoms of $\mathrm{Al}, \mathrm{Si}$ and $\mathrm{O}$, accordingly it can be synthesized with raw materials such as kaolin. Kaolin is an inert and inactive material, so it requires activation to convert to metakaolin by calcination. The silica and alumina content in the metakaolin can be separated through leaching by acid, to obtain a rafinat namely Leached Metakaolin (LMK) and extract that contain a high of alumina. Both of the process conditions of calcinating kaolin and leaching metakaolin will affect the results of the separation of silica and alumina.

There are few papers reporting on leaching metakaolin. Ajayi [5], Mamani [6] and Adeoye [7] have successfully separated silica and alumina in metakaolin using acid and reported the result a silica-rich solid as source of $\mathrm{SiO}_{2}$ for synthesis zeolite. However, they did not regard to the importance of alumina-rich solutions that can be used as a source of $\mathrm{Al}_{2} \mathrm{O}_{3}$ for ASA. Based on this description, researcher have used valuable opportunities to use kaolin in total, using extracts from the metakaolin leaching process as an alumina source for ASA synthesis.

The main purpose of this paper is to present the results of synthesis ASA using extract leaching metakaolin, that focus on studying the effect of ASA synthesis condition on pore structure and crystallinity.

\section{Materials and methods}

\subsection{Materials and reagents}

The material and chemical used in ASA synthesis include: Indonesian Kaolin Belitung, a technical grade of chemicals $\mathrm{HCl} 10 \%$, Ammonia solution $10 \%$, Sodium Silicate and aquademineral.

\subsection{Experimental set-up}

Synthesis ASA uses the extract of metakaolin leaching as alumina source, consisting of several working steps, namely:

\subsubsection{Preparation of alumina solution from metakaolin}

The process starts with activating kaolin through calcination process in the furnace at a temperature of $700^{\circ} \mathrm{C}$ for 2 hours, so that the amorphous phase of metakaolin is formed. The separation of alumina content was done from metakaolin through a leaching process. The suspension of metakaolin in $\mathrm{HCl} 2.5 \mathrm{M}$ was determined with weight ratio of $\mathrm{HCl} 2.5 \mathrm{M} /$ metakaolin

* Corresponding author: endang.srirahayu @ polban.ac.id 
solids at $10 \mathrm{w} / \mathrm{w}$ [6], at a temperature of $100^{\circ} \mathrm{C}$, for 2 hours, by stirring speed of $170 \mathrm{rpm}$. Furthermore, the leaching products are separated by filtration. Leaching extracts were characterized using the Atomic Absorption Spectrophotometer (AAS) to determine $\mathrm{SiO}_{2}$ and $\mathrm{Al}_{2} \mathrm{O}_{3}$ content.

\subsubsection{Synthesis of ASA}

Synthesis of ASA was done by co-precipitation method, by adopting a US Patent 6399530 [4], that preceded by neutralization process to form a sol phase, stabilizing, followed by introducing a silica solution, and then aging to form an amorphous phase.

Synthesis with a co-precipitation method, using acid of alumina solution and base of Ammonia solution $10 \%$, for neutralizing step. Neutralizing time, ratio of $\mathrm{Si} / \mathrm{Al}$ and aging time were used as variable process. While, a $\mathrm{pH}$ and temperature of neutralization are as independent process variable, of 7-8 and $50-55^{\circ} \mathrm{C}$, respectively.

The equipment for ASA synthesis shown in Figure 1 includes a laboratory glass reactor and support tool such as hot plate, magnetic stirrer, thermometer. The others else, such as universal $\mathrm{pH}$ paper, Buchner funnel, Whatman filter paper, vacuum pump, mortar, measuring cup, impermeable plastic, oven and furnace.

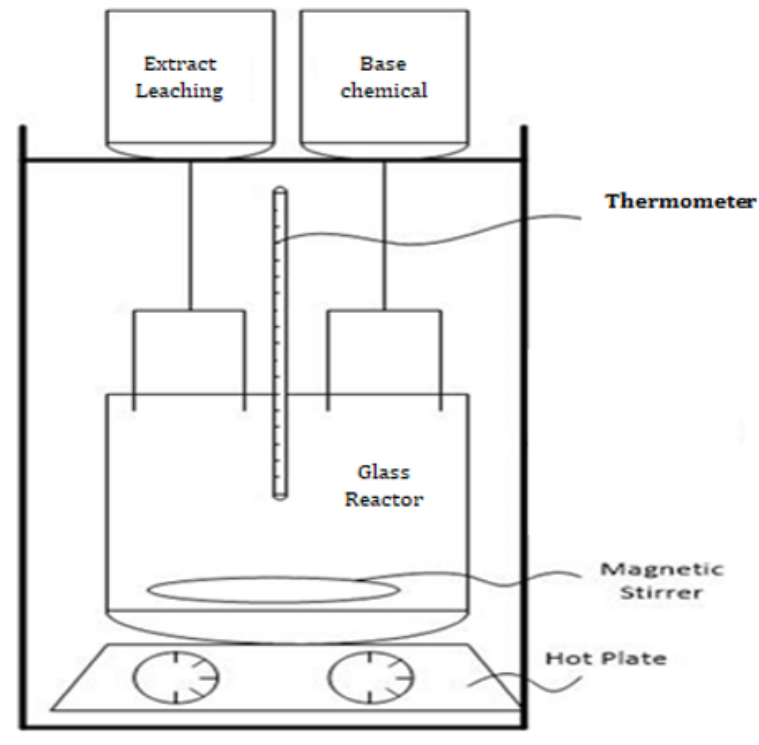

Figure 1. Typical reactor and support tools

\subsubsection{Characterization of ASA}

The product was filtered and rinsed to a neutral $\mathrm{pH}$, dried in an oven with a temperature of $110^{\circ} \mathrm{C}$ for 8 hours, and analyzed by a NovaWin Quantachrome for pore structure, mineralogy analysis with instrument of XRD Brucker, and morphology analysis with instrument of SEM JEOL.

\section{Results and discussion}

\subsection{Dealumination metakaolin by leaching}

The alumina concentration in the extracts of metakaolin leaching in between 20-24 g / L was obtained by using $\mathrm{HCl} 2.5 \mathrm{M}$ at temperature of $100^{\circ} \mathrm{C}$ during 2 hours, which is used as an alumina source in ASA synthesis. Extracts of metakaolin leaching also contain $\mathrm{SiO}_{2}$ about $0.09 \mathrm{~g} / \mathrm{L}$.

\subsection{Synthesis of ASA from kaolin}

The synthesis of ASA using alumina from extract of metakaolin leaching was carried out by co-precipitation method, at temperature of $50-55^{\circ} \mathrm{C}$ and $\mathrm{pH}$ in between 78 for neutralizing stage using $10 \%$ ammonia solution to form sol, and at temperature of $50-55^{\circ} \mathrm{C}$ and $\mathrm{pH} 8-9$ for aging stage to form gel. The results of pore structure ASA shown in Table 1 and difractogram of ASA in FIG.2.

In the reaction of ASA synthesis, formation of sol and gel is written in equations (1) and (2), respectively:

$$
\begin{gathered}
\mathrm{Al}_{2}\left(\mathrm{SO}_{4}\right)_{3}+\mathrm{NaAlO}_{2}+12 \mathrm{OH}^{-} \rightarrow 3\left[\mathrm{Al}(\mathrm{OH})_{4}\right]^{-}+\mathrm{Na}^{+}+3 \mathrm{SO}^{-} \\
2 \mathrm{SiO}_{2}+3\left[\mathrm{Al}(\mathrm{OH})_{4}\right]^{-}+\mathrm{H}_{2} \mathrm{O} \rightarrow(\mathrm{SiO})^{--}+\mathrm{Al}\left(\mathrm{H}_{2} \mathrm{O}\right)\left(\mathrm{OH}^{-}\right)+3 \mathrm{OH}^{-}
\end{gathered}
$$

The effect of the $\mathrm{Si} / \mathrm{Al}$ ratio in the starting material on the ASA pore structure is not significant, as well as the influence of aging time. The $\mathrm{Si} / \mathrm{Al}$ ratio is predicted to be more likely to affect ASA acidity.

In general, the ASA products with base chemical of $\mathrm{NH}_{4} \mathrm{OH}$ solution have good pore structure, by using alumina solution of $20 \mathrm{~g} / \mathrm{L}$. It have a high of specific surface area and average pore diameter, which suited as a hydrocracking catalyst support. The ASA results are almost the same as the results obtained by C. Song (2002) that using $\mathrm{Al}_{2} \mathrm{O}_{3}$ solution above $40 \mathrm{~g} / \mathrm{L}$. As a comparison, Rahayu [8] produces a pore structure of ASA with a lower surface area of $372 \mathrm{~m}^{2} / \mathrm{g}$, when using a base chemical of $\mathrm{NaOH}$, a higher neutralization temperature and an aging temperature of $65^{\circ} \mathrm{C}$ and $60^{\circ} \mathrm{C}$, respectively. Therefore, in this study was used ammonia solution as a base chemical, which has proven its superiority to get a better pore structure, in addition to being supported by a lower process temperature.

\begin{tabular}{|c|c|c|c|c|c|}
\hline \multicolumn{3}{|c|}{ Synthesis Process ASA } & \multicolumn{3}{|c|}{ Pore Structure of ASA } \\
\hline Neutralizer & $\begin{array}{l}\text { Rasio } \\
\mathrm{Si} / \mathrm{Al} \text {, } \\
(\mathrm{g} / \mathrm{g})\end{array}$ & $\begin{array}{l}\text { Aging } \\
\text { Time } \\
\text { (Hour) }\end{array}$ & $\begin{array}{l}\text { Average } \\
\text { Pore } \\
\text { Diameter } \\
\text { (A) }\end{array}$ & $\begin{array}{c}\text { Specific } \\
\text { Surface } \\
\text { Area } \\
\left(\mathrm{m}^{2} / \mathrm{g}\right)\end{array}$ & $\begin{array}{c}\text { Tot } \\
\text { Pore } \\
\text { Vol } \\
(\mathrm{mL} / \mathrm{g})\end{array}$ \\
\hline \multicolumn{6}{|c|}{ Neutralizing, 60 meinutes } \\
\hline $\mathrm{NH}_{4} \mathrm{OH}$ & 0.22 & $\begin{array}{l}1 \\
3 \\
5 \\
1 \\
3 \\
5 \\
1 \\
3 \\
5 \\
\end{array}$ & $\begin{array}{l}79 \\
80 \\
70 \\
85 \\
80 \\
82 \\
97 \\
90 \\
88 \\
\end{array}$ & $\begin{array}{l}446 \\
462 \\
480 \\
510 \\
535 \\
535 \\
485 \\
544 \\
536 \\
\end{array}$ & $\begin{array}{l}0.88 \\
0.95 \\
0.85 \\
1.10 \\
1.07 \\
1.10 \\
1.18 \\
1.22 \\
1.17 \\
\end{array}$ \\
\hline \multicolumn{6}{|c|}{ Neutralizing, 40 minutes } \\
\hline $\mathrm{NH}_{4} \mathrm{OH}$ & 0.11 & $\begin{array}{l}1 \\
3 \\
5\end{array}$ & $\begin{array}{l}61 \\
59 \\
48\end{array}$ & $\begin{array}{l}458 \\
463 \\
479\end{array}$ & $\begin{array}{l}0.70 \\
0.93 \\
0.57\end{array}$ \\
\hline
\end{tabular}

Table 1. Pore structure ASA 
Even, Rahayu [9] has also done the synthesis of ASA by using achemicals synthetic of aluminum sulphate $\left[\mathrm{Al}_{2}\left(\mathrm{SO}_{4}\right)_{3} \cdot \mathrm{xH}_{2} \mathrm{O}\right]$ and Sodium Aluminate $\left(\mathrm{NaAlO}_{2}\right)$, and the ASAs product with an average of specific surface area of $383.5 \mathrm{~m}^{2} / \mathrm{g}$, average pore diameter of $80.7 \AA$, and total pore volume of $0.78 \mathrm{ml} / \mathrm{g}$ were obtained. This result is lower than the results of the study using extracts of metakaolin leaching. The possibility is the alumina in the extract of metakaolin leaching is more homogeneous than alum solution from synthetic chemicals, even this still has to be verified.

The diffractogram pattern of the synthesized ASAs are shown in Figure $2 a$, Figure $2 b$ and Figure $2 c$, that similar to the commercial ASA. Silica is required to provide acidic properties of ASA, however, the addition of $\mathrm{Si}$ in the synthesis of ASA may destroy the pore structure and affects the pore structure. In addition, the replacement of the $\mathrm{Al}$ atomic site by the $\mathrm{Si}$ atom can excessively remove the Bronsted acid-forming group ( $\mathrm{Si}$ $\mathrm{OH}-\mathrm{Al})$, which will decrease the Bronsted acid concentration [10].

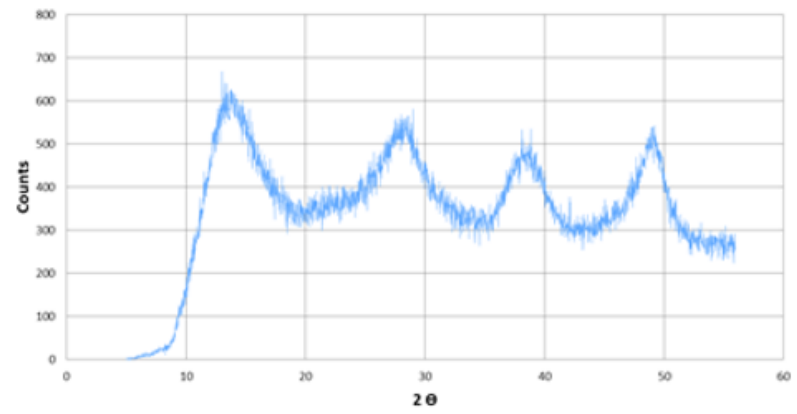

Figure 2a. The ASA with mass ratio $\mathrm{Si} / \mathrm{Al}$ of $0.11 / 1 \mathrm{w} / \mathrm{w}$

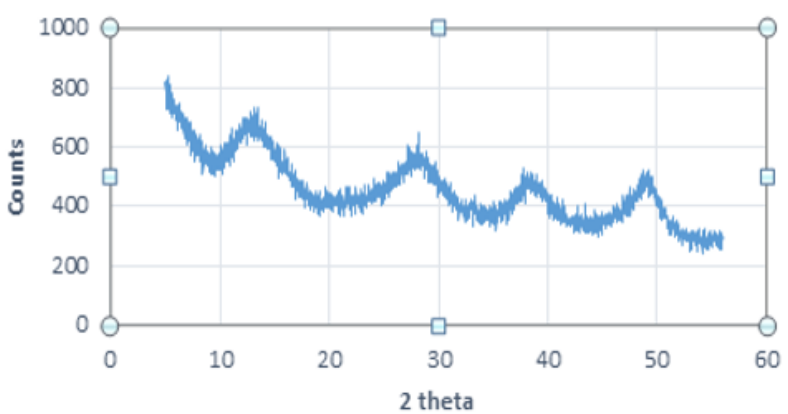

Figure 2b. The ASA with mass ratio $\mathrm{Si} / \mathrm{Al}$ of $0.22 / 1 \mathrm{w} / \mathrm{w}$

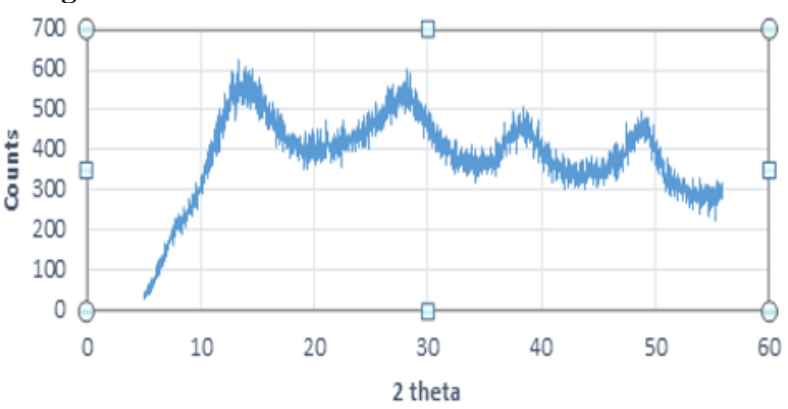

Figure 2c. The ASA with mass ratio $\mathrm{Si} / \mathrm{Al}$ of $0.33 / 1 \mathrm{w} / \mathrm{w}$

Figure 2a, Figure $2 \mathrm{~b}$ and Figure $2 \mathrm{c}$ show that the greater Si content in starting material in ASA synthesis, $\mathrm{Si}$ will occupy the Al place in the ASA with the greater amount too, so it adds an amorphous phase in ASA or less in crystallinity.

\section{Conclusion}

The results of ASA synthesis with a new method that is using extracts of metakaolin leaching from Indonesian origin Belitung kaolin was obtained, with a good pore structure and a low crystallinity. The increasing of $\mathrm{Si} / \mathrm{Al}$ ratio in starting material affects on the specific surface area of ASA, as well as with aging time. The product of ASA with a specific surface area of $510 \mathrm{~m}^{2} / \mathrm{g}$, an average pore diameter of $85 \AA$, a total pore volume of $1.1 \mathrm{~mL} / \mathrm{g}$, and an amorphous phase of 53\%-mass were observed. The effect of $\mathrm{Si} / \mathrm{Al}$ ratio and aging time in ASA synthesis is not significant to the pore structure, but apparently the time of neutralization can affect the pore structure significantly. The results of the ASA synthesis using this new method can match to the synthesis results of ASA using synthetic chemicals. It obatained a good pore structure, even alumina concentrations in the extract of metakaolin leaching lower than by using synthetic chemicals. It is predicted that the solubility of alumina in the metakaolin leaching extract is higher than when using synthetic chemicals.

Authors would like thanks to Directorate General of Research Reinforcement \& Development for funding this research through the National Competition Grants Program, PSN, 2018.

\section{References}

[1] Breck, D.W., Zeolite Molecular Sieves: Structure, Chemistry, and Use. John Wiley \& Sons, New York, 1974.

[2] Barrer, R. M., Zeolite Synthesis: An Overview, London, UK, 1990.

[3] Scherzer, J.,and Gruia, A. J., Hydrocracking Science and Technology, Marcel Dekker, Inc. New York, 1996.

[4] Song, C., Tingyu, L., Guangwei, C., Minghua, G. Amorf silica-alumina, a carrier combination and a Hydrocracking catalyst containing the same, and processes for the preparation thereof,US Patent 6399530, 2002.

[5] Ajayi, A.O., Atta, A.Y., Aderemi, B.O., and Adefila, S. S., Novel Method of Metakaolin Dealumination -Preliminary Investigation, Journal of Applied Sciences Research, 2010, 6(10): 1539-1546

[6] Mamani, W., A., Garcia, G., Hedlund, J., and Mouzan, J., Comparison between leached metakaolin and leached diatomaceous earth as raw materials for the synthesis of ZSM-5, Springer Plus, 2014, 3:292

[7] Adeoye, J.B., Omoleye. J.A. Development of Zeolit Y From Arobieye Mined Kaolin, 3rd International Conference on African Development Issues (CU-ICADI), 2016 
[8] Rahayu, E.S., Subiyanto, G., Imanuddin, A., Wiranto, Nadina, S., Ristiani, R., Suhermina, and Yuniarti, E., Kaolin as a Source of Silica and Alumina for Synthesis of Zeolite $\mathrm{Y}$ and Amorphous Silica Alumina, MATEC Web of conferences, 2018, 156, 05002.

[9] Rahayu, E. S., Conversion of Kaolin into Zeolite Y-Amorphous Oxide as a Catalyst Support for Hydrocracking Catalyst, Dissertation Report, 2015.

[10] Chizallet, C., and Raybaud, P., Chem. Phys. Chem., 2010, 11, 105. 